\title{
The legal character of ancillary customary marriages
}

\section{JC Bekker}

$L L B L L D$

Honorary Professor in Department of Private Law, University of Pretoria

\section{Buchner-Eveleigh}

$L L B$ LLM LLD

Senior Lecturer in Department of Private Law, University of Pretoria

\section{OPSOMMING}

Die regsaard van aanvullende gebruiklike huwelike

Die Wet op Erkenning van Gebruiklike Huwelike is 'n kernkomponent van Suid-Afrika se plurale regsbestel. Bykomstig tot die huwelike deur die Wet geskep, is daar egter ook ander, huwelike, wat as "aanvullende" huwelike beskryf sou kon word. Hierdie huwelike val uiteen in verskeie kategorieë, nl. 'n huwelik gesluit tussen twee vroue om die baar van kinders vir 'n betrokke lapa, huis of kraal te bewerkstellig; sororate huwelike; leviraatshuwelike; en, laastens, ukungena. In hierdie artikel word elk van bogenoemde bespreek en word daar, kortliks, ondersoek ingestel na die vraag of hierdie huwelik as sodanig erken kan word binne die bestek van die Wet op Erkenning van Gebruiklike Huwelike en die Handves van Regte.

\section{Background and purpose}

South Africa has a plural legal system consisting of the common law (applicable to everybody) and customary law (applicable to black South Africans only). The people to whom these laws apply are largely socially integrated but Africans, especially those who live in rural areas, follow traditional and customary practices and ways of living to varying degrees. For instance, family law among a mostly urban section of the population (particularly Whites) is based on notions of the nuclear family, whereas African families form extended social units consisting, broadly speaking, of all who belong to the family. ${ }^{1}$ The status of spouses and their children, therefore, is inextricably interwoven with their membership of the family. ${ }^{2}$

In the following outline Coertze 3 explains the concept of 'family' in black African communities:

Among the African peoples, including the Bafokeng the social structure is not composed of a number of separate nuclear family atoms, but of networks of

Bafokeng Family Law and Law of Succession (1987) 3

Bafokeng Family Law and Law of Succession (1987) 3.

Bafokeng Family Law and Law of Succession (1987) 3.

How to cite: Bekker \& Buchner-Eveleigh 'The legal character of ancillary customary marriages' 
family connections within which the reciprocal relationships between all members may also be governed by legal maxims.

The basic unit - and the primary interest of this study - is the conjugal-natal or nuclear family consisting of a man, his wife, and his children. This is the lapa unit, of which the father is the head and has authority over all the other members.

Africans nowadays are obliged to enter into a form of marriage akin to common law marriages. ${ }^{4}$ Moreover, succession is regulated by the Reform of Customary Law of Succession and Regulation of Related Matters Act (RCLSA). ${ }^{5}$ The lowest identifiable social unit still is the family, consisting of a man, his wife (or wives in former polygamous units) and all the children born out of this marital union (or unions in the case of polygamy). ${ }^{6}$

This description is not merely an idealised version of traditional African life: to this day Africans place a high premium on family solidarity and ancestor veneration. According to Mbiti: ${ }^{7}$

When (a man) gets married, he is not alone, neither does his wife 'belong' to him alone. So also the children belong to the corporate body of kinsmen, even if they bear only their father's name. Whatever happens to the individual happens to the whole group, and whatever happens to the whole group happens to the individual. The individual can only say: 'I am, because we are, and since we are, therefore I $a m, 8$

In the rural areas there are many such family homes in which a family head - male or female - plays an indispensable role in caring for all the occupants. These family homes (the household) may have little of monetary value worth distributing among heirs and may consist of a single house or a cluster of houses occupied by the family.

It is in accordance with these circumstances that African marriages (formerly called unions) were recognised as marriages in terms of the Recognition of Customary Marriages Act ${ }^{9}$ (RCMA). Marriages concluded in terms of customary law, ${ }^{10}$ for all purposes, were recognised as marriages. ${ }^{11}$

The RCMA largely focused on monogamous marriages but indirectly, included polygynous marriages. However, in addition to polygyny, there are a number of other unions that may be termed ancillary marriages. These unions formerly were called cognate unions, but as all customary marriages now for all purposes are marriages, the term 'ancillary

4 Recognition of Customary Marriages Act 120 of 1998

5 Act 11 of 2009.

6 See Reform of Customary Law of Succession and Regulation of Related Matters Act 11 of 2009.

7 African Religions and Philosophy (1969) 108-109.

8 Ibid.

9120 of 1998.

10 S1 of the Recognition of Customary Marriages Act 120 of 1998.

11 S2(1) of 120 of 1998. 
customary marriages' is more appropriate. The purpose of these further unions was not merely another conjugal relationship between a man and a woman but revolved around the preservation of the family and the continuation of the lineage. This purpose is expressed by Nhlapo:

Children are at the centre of the African concept of marriages as an arrangement serving interests wider than the immediate needs of the spouses. A man needed many sons to ensure the survival of the lineage and to increase his power within the clan, and daughters who by their marriages would swell his herds and create beneficial alliances with other clans. As members of the family children were also important participants in the household economy. The whole clan thus had an interest in the children of its members, their upbringing, socialization and eventually, marriage.

It would be perverse to argue for the abolition in Africa of the role of the wider family and the community in marriage. The positive aspects of this communal value are too clearly demonstrated. ${ }^{12}$

In the light of this understanding the authors describe the following ancillary marriages, as well as customary marriages akin to same-sex marriages, and, briefly, pose the question whether they can be recognised as marriages within the ambit of the RCMA and the Bill of Rights: ${ }^{13}$

(1) a woman marrying another woman to bear children for the lapa, house or kraal,

(2) marriages akin to same-sex marriages (which include true woman-towoman marriages), ${ }^{14}$

(3) the sororate,

(4) the levirate and

(5) ukungena.

What follows is a discussion of the different types or categories of ancillary customary marriages.

12 'The African Family and Women's Rights: Friends or Foe's?' 1991 Acta Juridica 135143

13 Ch 2 of the Constitution of the Republic of South Africa, 1996 (the Constitution).

14 Although these marriages are not ancillary marriages, they are discussed here to emphasise the fact that marriages between a woman and another woman for the purpose of bearing children for the house, lapa or kraal and same-sex marriages are different marriage institutions. 


\section{Discussion of the legal character of ancillary marriages}

\section{A woman marrying another woman to bear children for the lapa, house or $\mathrm{kraal}^{15}$}

A large volume of legal and related literature exists which deals with the subject of a woman marrying another woman for lapa, house or kraal, mostly written and interpreted by non-African writers. ${ }^{16}$ The most prominent reporting of the existence of this traditional form of marriage was by Oomen in 2000. ${ }^{17}$ According to Mokotong and Monney, ${ }^{18}$ the literature contains distorted information as it fails to appreciate the true nature of this marital practice. The authors state that generally this marital practice carelessly and erroneously has been described or translated in English as referring to a 'woman marriage or marriage involving a female husband or woman-to-woman marriage': descriptions which imply and advance a notion of lesbianism in this particular marriage practice. ${ }^{19}$ In a quest to record a 'true' African version of this marriage practice and address misunderstandings and the misrepresentation of this institution, they explain that this marriage is used as an intervention to save or revive a family name facing extinction. ${ }^{20}$ In other words, this form of marriage is resorted to if there is no one within a family or kraal to continue a family name in the form

15 This cultural marriage institution is known as go nyalela mosadi lapa in Sepedi or u malela musadzi muta in Tshivenda. Bennett Customary law in South Africa (2004) 198 noted that this type of marriage is commonly practised amongst the Pedi, Venda, Lovedu and Zulu societies in South Africa.

16 Mokotong and Monney 'A Study of Complex and Unfamiliar Customary Marriage Outside the Recognition of Customary Marriages Amendment Bill: Distortion of a Traditional Customary Marriage' 201327 Speculum Juris 78 79. See also literature cited therein, for example Krige 'Woman Marriage with Special Reference to the Lovedu: Its Significance for the Definition of Marriage' 1974 Journal of the International African Institute 11-37; Rautenbach and Meyer 'Lost in Translation: Is a Spouse a Spouse or a Descendant or Both in terms of the Reform of Customary law of Succession and Regulation of Related Matters Act' 20121 TSAR 149-160; Bekker Seymour's Customary Law in Southern Africa (1989) 147; Smith Oboler 'Is the Female Husband a Man? Woman/woman Marriage among the Nandi of Kenya' 198019 Ethnology Journal 69-88; Bonthuys 'Race and Gender in Civil Union Act' 200723 SAJHR 526-542; Oomen 'Traditional Woman-towoman Marriages and the Recognition of Customary Marriages Act' 2000 63 THRHR 274-282.

172000 THRHR 274.

182013 Speculum Juris 78.

19 Mokotong and Monney 2013 Speculum Juris 78. See also Armstrong 'Uncovering Reality: Excavating Women's Rights in African Family Law' 1993 International Journal of Law and the Family 314 316; Bonthuys 'Possibilities Foreclosed: The Civil Unions Act and Lesbian and Gay Identity in Southern Africa' (2008) http://sex.sagepub.com/content/11/6/726.full. pdf + html (last accessed 2015-09-15) 730 . 
of procreating and bearing offspring. Factors that may contribute to the absence of a biological family member to carry the family name, for example, are the death of the family head survived by the wife only; death by the family head survived by the wife and married daughters only; a childless woman with no brothers or sisters ${ }^{21}$ or a purely childless or barren woman. ${ }^{22}$

Mokotong and Monney ${ }^{23}$ describe this marriage as

a traditional form of marriage in which a woman is married into a family (lapa/house/kraal) to revive and continue with the family name of her newly parent-in-law. It must be pointed out that this form of marriage does not result in the bride becoming a couple to a parent-in-law or becoming someone's wife ... All various requirements for the conclusion of a valid customary marriage e.g. consent of the bride, negotiations with her family, payment of lobolo/magadi, exchange of gifts, transfer of the bride and celebration of the wedding are also observed. But the bride does not become the wife of or become a couple to her parent-in-law. Go nyalela mosadi lapa is not a marriage between one woman and another.

Upon the conclusion of a marriage the bride becomes the woman's daughter-in-law and not the wife of the woman and (the bride) refers to the woman as parent/mother-in-law. ${ }^{24}$ The woman married for the purposes of reviving the lapa has a duty to continue the family name of her new parent-in-law. If the woman already has children, her children automatically assume the surname of their new family and they will continue the family name. The woman and her children thus become the descendants of their new family or parent-in-law. ${ }^{25}$ If the woman has no children, a suitable, specially chosen, male partner normally will be selected for the daughter-in-law. ${ }^{26}$ The bride's children refer to the woman (parent-in-law) as grandmother (mmakgolo). ${ }^{27}$ The bride does not relinquish control, guardianship or any parental rights over her existing or future children, rather the children remain the bride's children and attain the status of the woman's (or, parent-in-law's) grandchildren. ${ }^{28}$

Oomen $^{29}$ also correctly called the parent-in-law or older woman a grandmother (mmakgolo). She then referred to the same grandmother as

\footnotetext{
21 Oomen 2000 THRHR 274.

22 Mokotong and Monney 2013 Speculum Juris 83.

23 Ibid.

24 Mokotong and Monney 2013 Speculum Juris 87, 94.

25 Mokotong and Monney 2013 Speculum Juris 84.

$26 \mathrm{Ibid}$. See also Bonthuys http://sex.sagepub.com/content/11/6/726.full.pdf + html 730; Bekker in Seymour's Customary law in Southern Africa 147 where he gives an account of such marriage process among Venda traditional communities.

27 Mokotong and Monney 2013 Speculum Juris 94.

28 Ibid.

29 Oomen 2000 THRHR 275.
} 
a female husband ${ }^{30}$ in order to show that the younger woman is her wife. According to Mokotong and Monney, Oomen's description fails to understand and appreciate the importance of calling the older woman a grandmother. In calling her grandmother the community by no means infers that the older woman is in a position equivalent of a spouse or a partner to a younger woman. ${ }^{31}$ This misconception was entrenched in section 3(1) of the Reform of Customary Law of Succession and Regulation of Related Matters Act (RCLSA). ${ }^{32}$ This section created a certain group of women who qualify as spouses for purposes of intestate succession. Section 2(2)(c), read together with section 3(1), of the RCLSA adopts an inclusive conception of the term 'spouse' for the purposes of intestate succession by providing that 'any woman who was married to another woman under customary law for the purpose of providing children for the deceased [woman's] house ..., if she survives the deceased, [must] be regarded as a descendant of the deceased'.

No sexual relationship arises in this form of marriage between the bride and her parent-in-law. ${ }^{33}$ Oomen's description of this type of marriage makes it explicit that it is different from same-sex marriages. She emphatically states that this form of marriage and same-sex marriage are entirely different marriage institutions. ${ }^{34}$ The absence of conjugal rights in this form of marriage is also confirmed by Smith Oboler $^{35}$ and Bonthuys. ${ }^{36}$ By way of contrast, the true nature of samesex marriage is to be found in the fact that it creates consortium omnis vitae, 3738 in other words, a same-sex marriage is contracted in response to the sexual emotions or attractions of the parties involved. The form of marriage as described by Oomen lacks this foundational function. ${ }^{39}$

30 Brien in 'Female husbands in Southern societies, in sexual stratification: A cross cultural view' (undated) http:www.angelfire.com (last assessed 201509-19) writes that the term 'female husband' refers to a woman who takes the legal and social roles of husband and father by marrying another woman according to the approved rules and ceremonies of the community.

31 Mokotong and Monney 2013 Speculum Juris 86.

32 See also Mokonong and Monney 2013 Speculum Juris 87.

33 Mokotong and Monney 2013 Speculum Juris 84.

34 Oomen 2000 THRHR 280.

351980 Ethnology Journal 80.

36 Bonthuys http://sex.sagepub.com/content/11/6/726.full.pdf + html 730.

37 With reference to Best v Samual Fox 1952 ALL ER 394, consortium can be explained as companionship, love, affection, comfort, mutual services, sexual intercourse - all belong to a married state. See also Grobbelaar $v$ Havenga 1964 (3) SA 522 (N) 525; Peter v Minister of Law and Order 1990 (4) SA 6 (E) 9F.

38 National Coalition for Gay and Lesbian Equality $v$ Minister of Home Affairs 2002 SA 1 (CC).

39 Mokotong and Monney 2013 Speculum Juris 93. 
From the above the form of marriage under discussion emanates as a result of peculiar circumstances and thus can be termed a special kind of marriage. It is also important to note that from its inception this form of marriage has not been popular: ${ }^{40}$ it has always been a form of marriage resorted to by few members of the tribal community. Notwithstanding this qualification, empirical evidence shows that this form of marriage is still concluded and celebrated in some African tribes. ${ }^{41}$

The RCMA makes no explicit provision for this type of marriage and appears not to allow or provide for the accommodation of this type of marriage. Most commentators ${ }^{42}$ are of the view that the RCMA simply equates customary with civil marriages concluded in terms of the Marriage Act ${ }^{43}$ as many of the requirements and consequences that the Act imposes in respect of customary marriages are the same as those which apply to civil marriages. According to Himonga ${ }^{44}$ the nearly complete substitution by the Act of the customary law consequences of a customary marriage with the consequences which apply in a civil marriage has created a 'common law African customary marriage'. Bakker ${ }^{45}$ goes further and states that customary marriages have been turned into civil marriages in which polygyny is permitted. Bekker and Van Niekerk ${ }^{46}$ state that customary marriages have become civil marriages in all but name. Thus, the RCMA retains and enforces a single, homogeneous, cultural version of customary marriage. According to Mokotong \& Monney, ${ }^{47}$ the Act gives legal recognition to customary marriages conducted according to customary law involving heterosexual couples (this includes both monogamous as well as polygamous marriages). It can be argued, because customary marriage practices manifest different and unique features from the recognised conventional customary marriage in terms of the RCMA, that there is no leeway to interpret the Act to accommodate the marriage practice that has been described above.

40 See Warmelo and Phophi Venda Law Part 1: Betrothal Thaka, Wedding (1948) 33; Mokotong and Monney 2013 Speculum Juris 83.

41 Mokotong and Monney 2013 Speculum Juris 92.

42 See Himonga 'The Advancement of African Women's Rights in the First Decade of Democracy in South Africa: The Reform of Customary Law of Marriage and Succession' 2005 Acta Juridica 82; Bakker 'Die Civil Union Act, Draft Domestic Partnership Bill en Moontlike Deregulering van die Huwelik' 200934 Journal for Juridical Science 1; Bekker and Van Niekerk 'Gumede $v$ President of the Republic of South Africa: Harmonising or the Creation of New Marriage Laws in South Africa?' 200924 SA Public Law 206 214.

43 Marriage Act 25 of 1961.

442005 Acta Juridica 8284.

45200934 Journal for Juridical Science 117

46200924 SA Public Law 206214.

472013 Speculum Juris 81. 


\section{Marriages akin to same-sex marriages}

A clear account of true woman-to-woman marriages, for example, is reported to exist among traditional healers known as sangomas. ${ }^{4}$ The sangomas derive many of their powers from their relationship with the ancestral spirits who, it is believed, choose or approve of ancestral wives for both male and female sangomas. A female traditional healer, on the instruction of the ancestral spirit, will marry a so-called ancestral wife. The functions of these wives are to assist the sangomas in their healing ceremonies and practices. ${ }^{49}$ Recent research indicates that sexual relations take place between the female sangomas and their wives ${ }^{50}$ and there is clear evidence that marriages between men also exist. Louw ${ }^{51}$ describes in the 1950s and 1960s marriages between men were publicly celebrated in the township of Mkhumbane in Natal. Moodie ${ }^{52}$ also gives an account of early mine marriages which were publicly celebrated between older migrant workers and younger men on the mines.

Although these marriages are not widespread or numerous in African communities, they nevertheless demonstrate that the customary law concept of marriage was flexible enough to accept and accommodate different family formations long before the enactment of the Civil Union Act. ${ }^{53}$ These marriages demonstrate no discernible difference from same-sex marriages legalised by the Civil Union Act. ${ }^{54}$

It is stated above ${ }^{55}$ that the RCMA simply equates customary and civil marriages and, therefore, retains and enforces a single, homogeneous, cultural version of customary marriage. The Act gives legal recognition to customary marriages conducted according to customary law only involving heterosexual couples (both monogamous as well as polygamous marriages). In addition, various sections in the Act explicitly

48 See Mokotong and Monney 2013 Speculum Juris 89; Bonthuys http:// sex.sagepub.com/content/ 11/6/726. full.pdf + html 731 .

49 Bonthuys http://sex.sagepub.com/content/11/6/726.full.pdf + html 731.

50 See Bonthuys http://sex.sagepub.com/content/11/6/726.full.pdf $+\mathrm{html} 731$; Nkabinde and Morgan 'This has Happened Since Ancient Times .... It's Something You are Born with: Ancestoral Wives amongst Same-Sex Sangomas in South Africa' in Morgan and Wieringa (eds) Tommy Boys, Lesbian Men and Ancestral Wives: Female Same-Sex Practices in Africa (2005) 231-260; Mokotong and Monney 2013 Speculum Juris 90.

51 'Mkhumbane and the New Traditions of (Un)African Same-Sex Weddings' in Morrell (ed) Changing Men in Southern Africa (2001) 287-96. See also Bonthuys http://sex.sagepub.com/content /11/6/726.fu 1l.pdf + html 731 .

52 'Black Migrant Mine Labourers and the Vicissitudes of Male Desire' in Morrel (ed) Changing Men in Southern Africa 297-315. See also Bonthuys http://sex.sagepub.com/content/11/6/726.full.pdf + html 731 .

53 Civil Union Act 17 of 2006.

54 The legislation was adopted as a direct result of the case of Minister of Home Affairs $v$ Fourie 20061 SA 542 (CC). The Act defines a civil union as 'a monogamous, voluntary union of two persons who are at least 18 years of age, which is solemnised and registered in accordance with the procedures prescribed in the Act'. The term 'civil union' includes a marriage and a civil partnership concluded in terms of the Act. 
make use of the words 'husband' and 'wife' and not merely of the term 'prospective spouses': 56 'husband' and 'wife' refer to spouses of the opposite sex only. Therefore the RCMA does not provide for so-called customary same-sex marriages, whether they were concluded before or after the coming into operation of the Act.

Same-sex marriages have gained legal recognition by way of the Civil Union Act in fulfilment of the constitutional dispensation opposing unfair sexual and gender discrimination. The Act is currently the only means available to same sex couples who want to obtain full legal recognition of their relationship. ${ }^{57}$ In others words, if same-sex couples, including those joined in customary same-sex marriages, want their marriage to have legal recognition, that marriage must be solemnised and registered in terms of the Civil Union Act.

\section{The sororate}

In African customary law, ${ }^{58}$ if a married woman is infertile or dies young or without having borne children, the husband's family has a right to approach the woman's family and ask that he be given a substitute (or seed raiser). ${ }^{59}$ The substitute could be an unmarried sister or another female relative of the infertile or deceased woman who has to bear children for the house of the infertile or deceased wife. ${ }^{60}$ This practice is referred to as a sororate union.

This practice stems from the marriage agreement between the husband's and wife's families and is connected to the function and significance of marriage goods (lobolo) delivered by a husband to his wife's family. ${ }^{61}$ Thus, this practice can be properly understood only if one takes cognisance of the nature of the marriage agreement and the

56 See for example s 1 which defines lobolo as 'the property in cash or in kind, whether known as lobolo, ..., which a prospective husband, or the head of this family undertakes to give to the head of the prospective wife's family in consideration of a customary marriage' and s 6 which expressly provides that 'the wife has on the basis of equality with her husband and subject to the matrimonial property system governing the marriage, full status and capacity, including the capacity to acquire assets and to dispose of them, to enter into contracts and to litigate, in addition to any rights and powers that she might have at customary law'. Further reference can also be made to ss 7(4)(b), 7(5), 7(6), 8(4)(b) and 10(1).

57 Heaton South African Family Law (2010) 195 fn 19, 201.

58 The study will limit itself to the Pedi, Xhosa and Tswana customs.

59 In Pedi custom it is not only the man's duty but the woman, of her own volition, will approach her parents and request them to give her a sister to help her. See Mönnig The Pedi (1967) 203.

60 Bennett Customary law in South Africa (2008) 355; Olivier Die Privaatreg van die Suid-Afrikaanse Bantoetaalsprekendes (1989) 103; Mahlobogwane 'Surrogate Motherhood Arrangements in South Africa: Changing Societal 'Norms?' 201327 Speculum Juris 45.

61 Boonzaaier and Hartman 'Regsimplikasies van die Sorroraat by die Tsonga van Gazankulu’ 198811 SA Journal of Ethnology 99107. 
special significance and function of lobolo. From sources consulted, the functions of lobolo, amongst others, are to legalise the marriage, ${ }^{62}$ ensure proper treatment of the wife by the husband and his family, legitimize the children born from the woman and to transfer the reproductive capacity of the woman from her family into that of her husband. ${ }^{63}$ Thus lobolo plays an indispensable function in providing legitimate offspring and increasing the lineage of the husband and his family group. By accepting the marriage goods, the wife's family undertakes that she will honour her child-bearing responsibilities towards her husband and his family, even if circumstances beyond her control make it impossible for her to fulfil the responsibilities. ${ }^{64}$ This view is in agreement with that of Mönnig, ${ }^{65}$ who defines a customary marriage as follows:

Marriage ... is not an individual affair, legalising the relationship between a man and a woman, but a group concern, legalising a relationship between two groups of relatives...

If the wife cannot fulfil her child-bearing responsibilities, her father has a moral obligation to provide a substitute who can bear children for the husband. ${ }^{66}$ This arrangement does not call for the conclusion of a separate marriage with the substitute. ${ }^{67}$ The customary law position is that the substitute becomes an additional asset to the house of her sister. No additional lobolo is due ${ }^{68}$ because the arrangement is that she is considered to be the womb of the original wife and, because she is the womb, she has to raise that house. ${ }^{69}$ She has the rights and duties of an ordinary wife, ${ }^{70}$ but the children borne by her belong to the house of her

62 Lobolo is not prescribed as a requirement in the Recognition of Customary Marriages Act but most commentators confirm that it is still a requirement for a valid customary marriage. For instance, Jansen 'Customary Family Law' in Rautenbach and Bekker (eds) Introduction to Legal Pluralism (2014) 105 states that 'lobolo embodies and expresses the views and convictions of the African community in terms of the distinction between a real and binding marriage and an informal relationship'. See Boonzaaier and Hartman 1988 SA Journal of Ethnology 107; Olivier Die Privaatreg van die Suid-Afrikaanse Bantoetaalsprekendes 101.

63 Bekker and Koyana 'The Legislative Reconstruction of Customary Law of Marriage' 201477 THRHR 23 29; Bekker Seymour's Customary Law in Southern Africa 150; Olivier Die Privaatreg van die Suid-Afrikaanse Bantoetaalsprekendes 101; Boonzaaier and Hartman 1988 SA Journal of Ethnology 99.

64 Customary marriages and procreation go hand in hand; without procreation, marriage is incomplete.

65 Mönnig The Pedi 129.

66 Boonzaaier and Hartman 1988 SA Journal of Ethnology 101. However, see Olivier et al Indigenous Law (1995) par 1.53 where he states that the husband may choose a seed raiser.

67 However, see Olivier et al Indigenous Law (1995) par 1.53 where he states that the union of a seed raiser is a normal customary marriage, concluded with its usual ceremonies.

68 Some form of consideration might be paid, but it is less than a full lobolo. See also Bekker and Koyana 2014 THRHR 33; Olivier Die Privaatreg van die Suid-Afrikaanse Bantoetaalsprekendes 103.

69 Mahlobogwane 2013 Speculum Juris 46.

70 Ibid. See also Maqutu Contemporary Family Law of Lesotho (1992)156. 
sister. ${ }^{71}$ The substitute is not given the rank or status of the childless wife. $^{72}$ The substitute virtually loses her personality ${ }^{73}$ and becomes absorbed into the house for which she has to bear seed. In the case of a deceased wife the substitute will replace her and, therefore, she assumes the deceased wife's position. The substitute wife has no status of her own but becomes the body of the woman for whom she has to bear seed. ${ }^{74}$

From the above it is evident that the institution of sororate was designed to remedy a woman's infertility or to fill a gap created by her death. The sororate union does not constitute a new house or lapa. ${ }^{75}$ Instead, it is described as a secondary union aimed at preserving an existing marriage and honouring the duties flowing from it. ${ }^{76}$ It is also interesting to note that the Reform of Customary Law of Succession Act also does not refer to the relationship between the deceased and the substitute woman as a marriage, but as a union: the reason for the union is for the purpose of providing children for the traditional house ${ }^{77}$ of the husband's spouse. ${ }^{78}$

The RCMA makes no express provision for sororate unions. The RCMA, which became operational on 15 November 2000, gives full recognition to all existing monogamous and polygamous customary marriages that comply with customary law requirements ${ }^{79}$ and establishes a set of minimum requirements for future customary marriages. ${ }^{80}$ It is argued, because these unions are not accompanied by typical marriage ceremonies and payment of lobolo, they do not constitute valid marriages and do not fall within the purview of the Act. ${ }^{81}$ It was argued above, ${ }^{82}$ because the Act equates customary with civil

71 Bekker and Koyana 2014 THRHR 33; Mahlobogwane 2013 Speculum Juris 46.

72 Bennett Customary law in South Africa 338; Maqutu Contemporary Family Law of Lesotho 156; Mahlobogwane 2013 Speculum Juris 45. The substitute will only assume the status of the childless woman should she die.

73 See Maqutu Contemporary Family Law of Lesotho 156 where he writes that the substitute wife "nevertheless become virtually a servant of the house she is married into and is completely under the shadow of the childless woman'.

74 Bekker and Koyana 2014 THRHR 33; Bennett Customary law in South Africa 346; Maqutu Contemporary Family Law of Lesotho 156. See also Bekker and Coertze Seymour's Customary Law in Southern Africa 4th ed (1982) 274-8.

75 Bennett Customary Law_in South Africa 198, 355.

76 Boonzaaier and Hartman 1988 SA Journal of Ethnology 99

77 'House' for purpose of the Act is defined in s 1 of the Act as the 'family, property, rights and status which arise out of the customary marriage of a woman'.

78 S 2(2)(b) read with s 3(1).

79 S 2(1) and (3).

80 S 3(1) provides that the prospective spouse must both be over the age of 18; they must consent to be married to each other under customary law; and the marriage must be negotiated and entered into or celebrated in accordance with customary law.

81 See also the South African Law Commission Report on Customary Marriages Project 90 (1998) 30.

82 Par 21 above. 
marriages, that it retains and enforces a single, homogeneous, cultural version of customary marriage. Therefore the RCMA does not include other forms of marriages which are recognised by African societies under customary law.

\section{Levirate}

The levirate is a system according to which a man marries the widow of his deceased brother and where the children born of the union are considered to be the progeny of the deceased brother, which enables them to remain in the deceased man's descent group.

\section{Hartman and Boonzaaier write:}

The levirate does not create a new marriage but merely perpetuates the existing union, the rights and duties of the substitute towards the widow, and those of the widow towards the substitute, are only slightly different from the reciprocal rights and duties that obtained between husband and wife before the former's death. Similarly, the substitute's duties towards the deceased's children are no different from those which any household head is normally expected to fulfil with regard to his own children. ${ }^{83}$

The custom is beneficial in that it safeguards the interests of the weakest links in society, namely fatherless children and widows. Maluleke ${ }^{84}$ indicates his approval of this custom in the following words

The African traditional culture has an almost infinite capacity for the pursuit of consensus and reconciliation, as opposed to being individualistic and competitive. Further, in terms of African culture, there are no orphans because a child is a child of a community in which the child lived. Decision making in the African culture (as expressed in terms of the principle of Ubuntu) is by consensus - productivity is optimised, not maximised, as the case may be in other cultures. Rewards are shared and so is suffering, as opposed to the context of an individualistic culture, where rewards are given according to individual merit and suffering is viewed as a penalty for one's carelessness. Sustainable competitive advantages come from loyalty to group goals in terms of Ubuntu.

Whelpton conveys a view which is similarly favourable, indicating that the widow has a choice but is unlikely to refuse partnership in a levirate union because it ensures that the deceased's lineage is perpetuated, that she and the children are taken care of and that they continue to have a male head who represents their interests in the wider family. No social welfare scheme or adoption achieves the same objectives.

83 'Verwekkings en Versorgingsimplikasies van die Leviraat by die Tsonga' 198811 SA Journal of Ethnology 80-81.

84 'Culture, Traditions, Customs, Law and Gender Equality' 201215 PER 1/428 17/428. 


\section{Ukungena}

The practice of ukungena is resorted to in the case of a widow, whereby a brother of the deceased husband or another near male relative is given access to the woman in order to father children on behalf of her deceased husband.

In terms of section 1(3)(f) of the Natal Code of Zulu Law ukungena is defined as

a union with a widow undertaken on behalf of her deceased husband by his full or half-brother or other paternal male relative for the purpose of either raising an heir if there is nobody to inherit the property rights attaching to the widow's hut or, if she has male issue, of increasing the nominal offspring of the deceased. ${ }^{85}$

Bekker $^{86}$ says the reasons for the perpetuation of the custom are the following:

Since a widow continues to keep her status as 'wife' at her husband's family home after his death, she is expected to continue to give effect to one of the main objects of matrimony, namely, the procreation of children; no widow who is young enough to bear children is required to live a chaste life after her husband's death. In most tribes, however, custom leads her husband's relatives to prefer that such children should be fathered by a man of their own blood, rather than by an outsider to the family group to which they belong. If possible, therefore, she will be induced to accept as a consort one of her husband's male relatives. She cannot be compelled.

The union does not create a legal obligation between the parties and it may be terminated unilaterally by either one of the parties. In traditional customary law the status of the children born from the ukungena union vis-à-vis children born from the marriage had to be resolved. In terms of the RCLSA the family head's estate would be wound up and cannot be revived after his death: children born from an ukungena union would succeed to their mother's estate. Vis-à-vis the male ukungena consort such children would be regarded as his extra-marital children who could inherit from him, but in terms of the common law of intestate succession. As the reason for the custom, namely the continuation of the family home, falls away by the statutory devolution of the deceased's estate (including the family home) the deceased's wife, the children and the consort find themselves in a legal vacuum.

If people should enter into an ukungena relationship not knowing that it has lost its traditional role - it has no legal effect - they will have to make alternative arrangements such as a will, to govern the patrimonial consequences of ukungena relationships.

85 Proc R151 of 1987 . The Act is to be repealed, but the repeal has not been effected yet. It is not suggested that it is current law, but it serves as a reflection of the nation.

86 Seymour's Customary Law in Southern Africa 286. 


\section{Cultural rights versus constitutional issues}

Advocates for the recognition of the ancillary customary marriages, as discussed above, argue that on constitutional grounds non-recognition of these marriages potentially violates, inter alia, the right not to be subject to unfair discrimination on the ground of culture 87 and the right to culture. ${ }^{88}$ Section 30 of the Constitution affords everyone the right to participate in the cultural life of his or her choice and section 31(1)(a) provides that persons belonging to a cultural community may not be denied the right to enjoy their culture.

The United Nations Educational, Scientific and Cultural Organisation (UNESCO) adopted the Draft Declaration on Cultural Diversity which provides:

Cultural rights are an integral part of human rights, which are universal, indivisible and interdependent... all persons have therefore the right to express themselves, and to create and disseminate their work in the language of their choice, particularly their mother tongue; all persons are entitled to quality education that fully respect their cultural identity; and all persons have a right to participate in the cultural life of their choice and conduct their own cultural practises, subject to respect for human rights and fundamental freedoms. 89

These cultural rights, however, may not be exercised in a manner which is inconsistent with human rights 90 or any of the provisions of the Bill of Rights. ${ }^{91}$ They, for instance, may not relegate women to an inferior status.

It can be argued that these ancillary marriages should not be recognised in their present form due to their patriarchal nature, as it undermine a woman's rights to equality and to dignity. ${ }^{92}$ Section 1 of the South African Constitution elevates gender equality and human dignity to be founding constitutional values. ${ }^{93}$ Ackermann J has stated that people are equal before the law and they enjoy the equal protection and the benefit of the law, which means that the law must protect and benefit all people equally with respect to their human dignity. ${ }^{94}$ In the case of S $v$

\footnotetext{
87 S 9(3)-(4) of the Constitution.

88 Ss 30-31 of the Constitution.

89 Art 5 of the Declaration, adopted at the United Nations Educational, Scientific and Cultural Organisation (UNESCO) General Conference Paris October 2001.

90 Ibid.

91 Ss 30 and 31(2).

92 Ss 9 and 10 of the Constitution.

93 The Constitution describes South Africa as "one sovereign state founded on the ... values of human dignity, the achievement of equality and the advancement of human rights and freedoms, non-racialism and nonsexism'.

94 Ackermann 'Equality and Non-discrimination: Some Analytical Thoughts' 2006 SAJHR 597-612.
} 
Makwanyane, ${ }^{95} \mathrm{O}$ Regan J explained the right to human dignity as follows:

Recognising a right to dignity is an acknowledgement of the intrinsic worth of human beings: Human beings are entitled to be treated as worthy of respect and concern. This right therefore is the foundation of many of the other rights that are specifically entrenched in ... the Bill of Rights.

In addition, the Constitution, the United Nation's Convention on the Elimination of All Forms of Discrimination against Women ${ }^{96}$ and the Optional Protocol to the African Charter on the Rights of Woman in Africa all require governments to take action to eliminate all forms of unfair sex and gender discrimination, even in the sphere of domestic relations. ${ }^{97}$

It can be argued that recognising these ancillary marriages in their present form perpetuates the social inequality of African women based on gender. However, Nhlapo ${ }^{98}$ disputes the claim by stating

In the context of a subsistence economy the very rules that appeared designed for the subjection of women often operated to ensure their security. The economic priorities underlying the pre-eminence of marriage and large families produced practices which worked in part to ensure that no woman was left without someone directly responsible for her maintenance.

Bekker ${ }^{99}$ opines that there is more to customary law than is perceived and that it is wrong to say that customary rules constitute another form of inequality and discrimination. African traditional practices, therefore, were not considered detrimental, although they are currently. There is a viewpoint which suggests that consideration should be given to people who adhere to cultural and traditional practices, such as a woman marrying another woman for lapa, the sororate and levirate. Quiet a number of people do not find these practices offensive as it is part of the culture of people adhering to these marital practices for very real and practical reasons. According to Robinson ${ }^{100}$ culture and customs are valuable and important parts of people's lives and women experience some aspects of customary law as affirming. The positive aspects of

951995 (3) SA 391 (CC) 328.

96 The Convention was adopted in 1979 by the United Nations General Assembly and came into force on 3 Sept 1981. South Africa signed the Convention in January 1993 and ratified the Convention on 15 December 1995, without entering any reservations.

97 S 9 of the Constitution, art 5(a) of the Convention and art 2(1) of the Protocol. Art 5(a) of the Convention provide that states parties are obliged ' $[t]$ modify the social and cultural patterns of conduct of men and women, with a view to achieving the elimination of prejudices and customary and all other practices which are based on the idea of inferiority or superiority of either of the sexes or on stereotyped roles of men and women'.

981991 Acta Juridica 135.

99 'How Compatible is African Customary Law with Human Rights? Some Preliminary Observations' 199457 THRHR 440-447.

100 Robinson 'The Minority and Subordinate Status of African Women under Customary Law' 199511 SAHJR 457 469. See also Mahlobogwane 2013 Speculum Juris 56. 
customary law can be measured by the extent to which they affirm a woman's personhood or are not experienced as oppressive. According to Mahlobogane $^{101}$ it is evident that some human rights principles undermine or conflict with certain human dignity orientations that human rights are supposed to protect. For instance, in customary law the husband in a family is regarded as the head of the family, whereas human rights afford his wife equal rights. Male leadership is an ancient supposition of family life.

On the other hand, Bekker and Koyana argue that these traditional marriage practices limit the woman's individual freedom of choice. ${ }^{102}$ Mahlobogane ${ }^{103}$ points out that customary marriage essentially is an agreement between two families in which the individual interest of the groom and bride, though implicitly or formally recognised, are a subordinate element to the wider dominating interests of their families. ${ }^{104}$ An individual exists as a member of a group and, consequently, an individual's rights are subject to the interests of the group. Mahlobogane ${ }^{105}$ further advances that African people consider the culturally universal values guaranteed by the authority of a super human being first before individual considerations and believe that the ancestors will bring harm upon those who ignore the ancestors and break the laws of the family. Women, who are ostensibly willing role-players, within these social circumstances are expected to obey. ${ }^{106}$

It is important to note, although African traditional marriage practices are becoming obsolete, ${ }^{107}$ these practices are not experienced as disruptive in the African communities that have institutionalised them within socially-accepted patterns of marriage. It is the authors' opinion that these practices promote social cohesion and unity and are not discriminatory, oppressive and dehumanising.

\section{Conclusion}

From the above discussion it is clear that ancillary unions and true woman-to-woman marriages are not recognised as marriages within the ambit of RCMA. As indicated above these practices are moving towards being obsolete. However the cultural importance of these unions and true woman-to-woman marriages should not be underestimated as it promotes social cohesion and unity and these practices are not experienced as discriminatory, oppressive and dehumanising in the communities that have institutionalised them.

1012013 Speculum Juris 55.

1022014 THRHR 33; Mahlobogwane 2013 Speculum Juris 56.

103 Mahlobogwane 2013 Speculum Juris 56.

104 See also Holleman Shona Customary law (1952) 73

1052013 Speculum Juris 56.

1062014 THRHR 33.

107 See Bekker and Koyana 2014 THRHR 33; Bennett Customary law in South Africa 355; Mahlobogwane 2013 Speculum Juris 58; Mokotong and Monney 2013 Speculum Juris 92; Bennett Customary law in South Africa 347. 
Some customs enjoy almost universal recognition among Africans in that they support the integrity of families, they perpetuate the name of the community (tribe) and they are not compulsory. They are sure in time to adapt to legal, social and economic change but, for the present, there is no necessity for change, especially as there is no need.

It is not known how many of these ancillary marriages exist. They are not registered or counted anywhere. Most, in any event, are of a personal and intimate nature. They are known by family members and members of the community, but are not publicly discussed. Family members involved in an unkungena union, of course, will know about it, but its existence is not public knowledge: the practice is a family affair. Questions may be raised about certain aspects, such as how and by whom the births of children born from an unkungena relationship are registered, but the status of the children is never debated. 